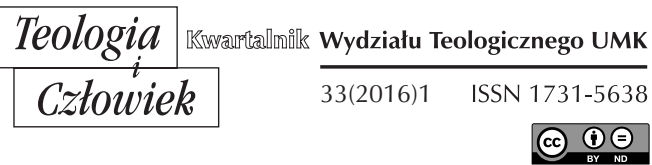

KS. DARIUSZ KWIATKOWSKI*

POZNAŃ

\title{
EKLEZJALNY WYMIAR GŁOSZENIA SŁOWA BOŻEGO W ŚWIETLE ADHORTACJI APOSTOLSKIEJ BENEDYKTA XVI VERBUM DOMINI
}

DOI: http://dx.doi.org/10.12775/TiCz.2016.001

\section{WSTĘP}

Konstytucja dogmatyczna o Objawieniu Bożym Dei verbum w rozdziale szóstym ukazuje miejsce i rolę Pisma Świętego w życiu i misji Kościoła. Dokument stwierdza najpierw, że całe przepowiadanie kościelne oraz sama religia chrześcijańska musi jednocześnie karmić się i kierować Słowem Bożym. Następnie, w odniesieniu do Kościoła, mówi: „Tak wielka zaś w słowie Bożym zawiera się moc i potęga, że staje się ono dla Kościoła podstawą i siłą żywotną, a dla dzieci Kościoła umocnieniem wiary, pokarmem duszy, czystym i trwałym źródłem życia duchowego"1. $\mathrm{Z}$ powyższej wypowiedzi soborowego dokumentu jasno wynika, iż bez

* Ks. prof. UAM dr hab. Dariusz Kwiatkowski jest kapłanem diecezji kaliskiej. Obecnie pracuje w WSD w Kaliszu i jest adiunktem Wydziału Teologicznego UAM w Poznaniu. Jest członkiem Rady Naukowej Czasopisma „Teologia i Człowiek” (kwiatkowski@post.pl).

${ }^{1} \mathrm{KO} 21$. 
Słowa Bożego nie ma Kościoła. Słowo Boże jest twórcą i fundamentem Kościoła i stanowi dla niego życiodajną siłę. Ono jest także mocą, która Kościół buduje, rozwija, ożywia i pogłębia jego życie wewnętrzne.

W tej wypowiedzi konstytucji Dei verbum łatwo zauważyć kontynuację postulatów zawartych wcześniej w konstytucji o liturgii Sacrosanctum concilium, która chciała, aby obficiej zastawić wiernym stół słowa Bożego i szerzej otworzyć skarbiec biblijny, tak by w określonej liczbie lat odczytać ludowi ważniejsze części Pisma Świętego. Zalecała także homilię, w której w ciągu roku liturgicznego przedstawiałoby się na podstawie świętego tekstu tajemnice wiary i zasady chrześcijańskiego życia ${ }^{2}$. Ogromne znaczenie Słowa Bożego w Kościele wynika z faktu obecności Chrystusa w głoszonym słowie. Konstytucja o liturgii powie wprost: „Jest obecny w swoim słowie, bo gdy w Kościele czyta się Pismo Święte, On sam przemawia"'.

Po Soborze Watykańskim II Kościół na nowo odkrywał rolę Słowa Bożego w swoim życiu. Można to zauważyć w nauczaniu Magisterium Kościoła, w opracowaniach teologicznych i w praktyce pastoralnej Kościoła, zwłaszcza w przypadku różnych ruchów kościelnych, które jako fundament swojej formacji obierały Słowo Boże. Chyba nie będzie przesadne stwierdzenie, że apogeum w dotychczasowym nauczaniu Magisterium dotyczącym Słowa Bożego w życiu Kościoła i każdego wiernego znajduje się w adhortacji apostolskiej papieża Benedykta XVI Verbum Domini, wydanej 30 września 2010 r. ${ }^{4}$

Celem artykułu jest ukazanie eklezjalnego wymiaru głoszenia Słowa Bożego w Kościele i w świecie. Zamierzony cel będzie realizowany w trzech punktach. Najpierw należy pokazać Kościół jako właściwe miejsce hermeneutyki Słowa Bożego, następnie wskazać na jego nieustanną obecność w Kościele i w końcu przedstawić, że głoszenie słowa Bożego stanowi posłannictwo Kościoła.

2 Por. KL 51-52.

${ }^{3} \mathrm{KL} 7$.

${ }^{4}$ Benedykt XVI, Posynodalna adhortacja apostolska o Słowie Bożym w życiu i misji Kościoła Verbum Domini, Kraków 2010 (odtąd: VD). 


\section{KOŚClÓŁ WŁAŚCIWYM MIEJSCEM HERMENEUTYKI SŁOWA BOŻEGO}

„To przede wszystkim miejcie na uwadze, że żadne proroctwo Pisma nie jest dla prywatnego wyjaśnienia. Nie z woli bowiem ludzkiej zostało kiedyś przyniesione proroctwo, ale kierowani Duchem Świętym mówili od Boga święci ludzie" (2P 1,20-21). Słowa św. Piotra dobitnie świadczą, że Pismo Święte jest wydarzeniem, o powstaniu którego zadecydowali nie tylko ludzie, którym zawdzięczamy konkretną postać tekstu, ale przede wszystkim Bóg, który uzdolnił ich do tego dzieła. Nie można traktować Pisma Świętego jako księgi ludzkiej i dlatego nie można jej interpretować tylko według kryteriów historyczno-literackich czy filozoficznych. Katolicka interpretacja tekstu biblijnego powinna odczytywać znaczenie dobrej nowiny przede wszystkim w życiu i w wierze Kościoła. Pismo Święte zostało powierzone Kościołowi i on bierze na siebie odpowiedzialność za właściwą interpretację Słowa Bożego ${ }^{5}$.

Papież Benedykt XVI przypomina, iż istniejący ścisły związek między słowem a wiarą wskazuje, że prawdziwa i autentyczna hermeneutyka Biblii jest możliwa tylko w wierze Kościoła. Wzorem staje się tutaj fiat Maryi, która usłyszała, przyjęła i wypełniła słowo tak, jak tego chciał Bóg. Odwołując się do nauczania św. Bonawentury, papież stwierdza, że bez wiary nie ma klucza umożliwiającego dostęp do Słowa Bożego ${ }^{6}$.

Ojciec Święty bardzo mocno podkreśla, że podstawowe kryterium hermeneutyki biblijnej brzmi następująco: „właściwym miejscem interpretacji Biblii jest życie Kościoła"7. I nie chodzi tutaj o to, że odniesienie do Kościoła stanowi zewnętrzne kryterium dla egzegetów, ale jest to wymóg samej natury Pisma Świętego i tego, w jaki sposób ono tworzyło się w czasie. Papieska Komisja Biblijna zwraca uwagę, że to właśnie tradycje wiary kształtowały środowiska życia, którego częścią była twórczość pisarska autorów Pisma Świętego. Tradycja ta ściśle wiązała się z uczestnictwem w życiu liturgicznym Kościoła, w działalności zewnętrznej konkretnych

${ }_{5}$ Por. J. Szlaga, Hermeneutyka biblijna, [w:] Wstęp ogólny do Pisma świętego, red. J. Szlaga, Poznań-Warszawa 1986, s. 215.

${ }^{6}$ Por. VD 29.

7 Tamże. 
wspólnot kościelnych, w ich świecie duchowym i w kulturze. Stąd od egzegetów wymaga się, aby interpretując Słowo Boże, wczuwali się w pełni w życie i wiarę wspólnoty wierzącej ich czasów ${ }^{8}$.

Konstytucja Dei verbum domaga się, aby Pismo Święte było odczytywane i objaśniane w tym samym duchu, w którym zostało napisane9 Oznacza to, że należy je traktować zgodnie $\mathrm{z}$ tym, czym ono jest naprawdę, czyli jako Słowo Boże, które objawia się za pośrednictwem ludzkich słów (por. 1Tes 2,13). Benedykt XVI zwraca uwagę, że to właśnie wiara Kościoła uznaje Pismo Święte za Słowo Boże. Papież cytuje w tym miejscu bardzo wymowną wypowiedź św. Augustyna: „nie wierzyłbym Ewangelii, gdyby nie skłaniał mnie do tego autorytet Kościoła katolickiego"10 i dodaje, że Duch Święty, który nieustannie ożywia życie Kościoła, uzdalnia do autentycznej interpretacji Pisma Świętego, które jest księgą Kościoła ${ }^{11}$.

Kolejnym świadectwem ze starożytności, przytaczanym przez Ojca Świętego Benedykta XVI, jest wypowiedź św. Hieronima, dla którego nieznajomość Pisma Świętego była równoznaczna $\mathrm{z}$ nieznajomością Chrystusa. Ten wielki znawca i czciciel Słowa Bożego w komentarzu do Księgi Izajasza pisał: „Nie możemy nigdy sami czytać Pisma Świętego. Spotykamy zbyt wiele zamkniętych drzwi i łatwo błądzimy. Biblia została napisana przez lud Boży i dla ludu Bożego pod natchnieniem Ducha Świętego. Jedynie $\mathrm{w}$ tej komunii z ludem Bożym możemy rzeczywiście dotrzeć z naszym »my« do istoty prawdy, którą Bóg chce nam przekazać"12. Poza tym Hieronim uważał, że eklezjalność interpretacji biblijnej nie jest wymogiem narzuconym z zewnątrz. Według niego Pismo Święte stanowi głos pielgrzymującego ludu Bożego i dlatego tylko w wierze tego ludu możemy w odpowiedni sposób zinterpretować i zrozumieć Biblię ${ }^{13}$.

${ }^{8}$ Por. Papieska Komisja Biblijna, Interpretacja Biblii w Kościele (15 kwietnia 1993), [w:] Interpretacja Biblii w Kościele. Dokument Papieskiej Komisji Biblijnej z komentarzami biblistów polskich, red. R. Rubinkiewicz, Warszawa 1999, s. 71.

$9 \mathrm{KO} 12$.

${ }_{10}$ Augustyn, Contra epistulam Manichaei quam vocant fundamenti, V, 6, PL 42, 176; cyt. za: VD 29.

11 Por. DV 29.

${ }^{12}$ Hieronim, Commentatorium in Isaiam libri, Prol., PL 24, 17; cyt. za: VD 30.

13 VD 30. 
Prawdziwa i autentyczna interpretacja Słowa Bożego musi harmonijnie współbrzmieć $\mathrm{z}$ wiarą Kościoła katolickiego. Bardzo ważne staje się tutaj osobiste doświadczenie spotkania i doświadczenia mocy Słowa Bożego. Papieska Komisja Biblijna podkreśla, że tekst biblijny może właściwie zrozumieć tylko ten, kto sam przeżył to, o czym mówi tekst $^{14}$. Doświadczenie pokazuje, że u osób, które bardziej otwierają się na życie Duchem Świętym, jednocześnie pogłębia się pragnienie Słowa Bożego i jego zrozumienie. Papież Benedykt XVI zauważa, że „Głębia autentycznego doświadczenia eklezjalnego sprzyja lepszemu zrozumieniu autentycznej wiary w odniesieniu do słowa Bożego; i na odwrót, trzeba powiedzieć, że czytanie w wierze Pism prowadzi do wzrostu życia eklezjalnego"15. Można zatem stwierdzić, że słuchanie Słowa Bożego bardzo mocno wprowadza w komunię kościelną z pielgrzymującymi w wierze i ją jednocześnie pogłębia.

Podsumowując, należy stwierdzić, że Ojciec Święty Benedykt XVI bardzo jasno naucza, iż zadanie autentycznego wyjaśniania słowa Bożego zostało powierzone Nauczycielskiemu Urzędowi Kościoła. Pismo Święte zostało z woli Bożej powierzone Kościołowi. On czuwa nad całym depozytem wiary zawartym w Słowie Bożym. Sensus Ecclesiae wyrażą się w tym, że Kościół naucza i sam się uczy. Oznacza to, że nie jest on ponad Słowem Bożym. Należy podkreślić, że nie może być żadnej rozbieżności pomiędzy tym, czego Kościół strzeże jako depozytu, i tym, co nieustannie pogłębiając, sam sobie przyswaja jako Słowo Boże $\mathrm{e}^{16}$.

\section{PERMANENTNA OBECNOŚĆ SŁOWA BOŻEGO W KOŚCIELE}

Papież Benedykt XVI w swojej adhortacji apostolskiej bardzo mocno akcentuje stałą i ciągłą obecność Słowa Bożego w Kościele i w jego życiu. Uprzywilejowaną przestrzenią dla Słowa Bożego jest liturgia Kościoła. Kościół z woli samego Chrystusa stał się „domem Słowa Bożego”. W Nim pozostało i zamieszkało odwieczne Słowo Boże - Logos, które

${ }^{14}$ Por. Papieska Komisja Biblijna, Interpretacja Biblii w Kościele (15 kwietnia 1993), s. 59-60.

15 VD 30.

16 Por. J. Szlaga, Hermeneutyka biblijna, s. 216. 
istniało od początku, i które było Bogiem. Przez Nie wszystko się stało i Jemu zawdzięcza swoje istnienie. To Słowo stało się ciałem i zamieszkało między ludźmi (por. J 1,1-14). W Kościele Słowo - Logos jest dziś głosicielem Słowa Bożego ${ }^{17}$.

Ojciec Święty, nazywając „liturgię uprzywilejowaną przestrzenią Słowa Bożego", najpierw wskazuje na szczególną relację, jaka zachodzi między Słowem a wspólnotą Kościoła. Papież podkreśla, że aby zbawcze orędzie mogło być przekazywane w każdym miejscu i w każdym czasie, Bóg Ojciec powierzył Kościołowi swego Jednorodzonego Syna, który jest odwiecznym, wypowiedzianym w czasie Słowem ${ }^{18}$. Benedykt XVI przedstawia obraz Kościoła „jako rzeczywistości określonej przez przyjęcie Słowa Bożego, które stając się ciałem, przyszło »zamieszkać wśród nas «" (por. J 1,14) ${ }^{19}$. Właśnie osoba Jezusa Chrystusa stanowi jego fundament. To pozwala mówić o wspólnocie eklezjalnej jako o domu Słowa. Syn Boży jest jednocześnie założycielem i twórcą Kościoła, który zawdzięcza swe istnienie całemu Jego życiu, postępowaniu, a przede wszystkim Jego śmierci i zmartwychwstaniu. Kościół został stworzony przez Słowo - Jezusa Chrystusa $^{20}$. Słowo Boże, ponieważ posiada wielką moc i potęgę, jest dla Kościoła podporą i żywotną siłą oraz przyczynia się do jego budowania i wzrostu. Ponadto ono utwierdza wiarę i jest pokarmem dla duszy oraz czystym i stałym źródłem życia duchowego. Św. Łukasz w Dziejach Apostolskich tak napisał o Słowie Bożym: „jest władne zbudować i dać dziedzictwo ze wszystkimi świętymi” (Dz 20,32) ${ }^{21}$.

Benedykt XVI zwraca uwagę na stałą obecność Chrystusa w życiu Kościoła. Podkreśla, że relacja między Chrystusem, który jest Słowem Ojca, a wspólnotą eklezjalną jest niezwykle żywotna. Dzięki tej relacji Słowo Boże jest stale obecne we wspólnocie Kościoła na mocy obietnicy

17 Por. VD 52.

18 Por. tamże, 17.

19 Tamże, 50.

${ }^{20}$ Por. S. Moysa, Słowo zbawienia, Kraków 1974, s. 135; por. M. Pyc, Verbum Dei. Chrystologiczna refleksja $w$ świetle adhortacji apostolskiej Benedykta XVI „Verbum Domini”, [w:] Teologia dogmatyczna. „Verbum Domini”, red. M. Antoniewicz, t. VI, Kraków 2011, s. 17-18.

${ }^{21}$ Por. KO 21; por. KKK 131; por. Wprowadzenie pastoralno-liturgiczne do Lekcjonarza mszalnego, Poznań 2011, n. 7. 
Chrystusa: „A oto Ja jestem z wami przez wszystkie dni, aż do skończenia świata” (Mt 28,20). Odwołując się do nauczania Jana Pawła II, Benedykt XVI zaznacza, że owa stała obecność Chrystusa przy człowieku urzeczywistnia się w Kościele, który jest Jego Ciałem. Dlatego Chrystus obiecał uczniom Ducha Świętego, który miał im wszystko wyjaśnić oraz stać się w świecie źródłem nowego życia (por. J 14,26) ${ }^{22}$. Już Sobór Watykański II nauczał: „Bóg, który niegdyś przemówił, bezustannie rozmawia z Oblubienicą swego umiłowanego Syna, a Duch Święty, dzięki któremu żywy głos Ewangelii rozbrzmiewa w Kościele, a przez Kościół w świecie, doprowadza wierzących do całej prawdy i sprawia, że słowo Chrystusa przebywa w nich obficie" (por. Kol 3,16) ${ }^{23}$.

Ojciec Święty stwierdza również, że Kościół, Oblubienica Chrystusa i nauczycielka słuchania, słucha Słowa Bożego i głosi je. W konstytucji dogmatycznej o Objawieniu Bożym Dei Verbum czytamy: „Sobór Święty ze czcią słuchając słowa Bożego i ufnie je głosząc..." ${ }^{24}$. To zdanie wskazuje także na to, iż Kościół jest podporządkowany Słowu. Jest ono w stosunku do niego suwerenne i nadrzędne. Dlatego też Kościół nabożnie i z pietyzmem wsłuchuje się w Słowo Boże, jednocześnie całkowicie poddając się zawartej w nim prawdzie. Nie głosi własnej nauki, ale przekazuje jedynie to, co sam Bóg powierzył mu w objawieniu. Kościół jest więc pierwszym słuchaczem słowa, który przyjmuje je, wierząc, że wypowiedzi Chrystusa, proroków i apostołów są autentycznym słowem Bożym. Taką postawą potwierdza, że słowo jest dla niego mocą, dzięki której żyje prawdą i jest jej niezmiennie wierny ${ }^{25}$.

Benedykt XVI zaznacza także, iż Kościół, słuchając słowa Bożego i głosząc je, czyni to w przekonaniu, że w głoszonym i słuchanym słowie oraz w sakramentach, „tu” i „teraz”, mówi do każdego z wiernych sam Jezus Chrystus. On oddaje się człowiekowi, by Go mógł przyjąć i odpowiedzieć w ten sam sposób. Kościół staje się środowiskiem, w którym można doświadczyć tego, o czym jest mowa w Prologu Ewangelii według

${ }^{22}$ Por. Jan Paweł II, Encyklika Veritatis splendor, 25, [w:] Encykliki Ojca Świętego Jana Pawła II, Kraków 2007, s. 733.

${ }^{23} \mathrm{KO} 8$; por. M. Pyc, dz. cyt., s. 18; por. VD 51.

${ }^{24} \mathrm{KO} 1$; por. VD 51.

25 Por. S. Moysa, Słowo zbawienia, s. 139. 
św. Jana: „Wszystkim tym jednak, którzy Je przyjęli, dało moc, aby się stali dziećmi Bożymi" (J 1,12) ${ }^{26}$.

Ojciec Święty, patrząc na Kościół jako dom Słowa, zwraca uwagę na świętą liturgię. Uznaje ją za uprzywilejowane miejsce, w którym Bóg przemawia do wspólnoty wiernych w teraźniejszości ich życia. Papież podkreśla, że każda czynność liturgiczna jest przesycona Pismem Świę$\operatorname{tym}^{27}$. To pokazuje, że związek między Słowem Bożym oraz liturgią jest praktycznie nierozerwalny. Można to wyrazić w następującym stwierdzeniu: „Liturgia jest Biblią w czynie, w działaniu”. W jakimś stopniu Biblia zrodziła się z liturgii i dlatego zajmuje w niej wyjątkowe miejsce. Ta wyjątkowość dotyczy przede wszystkim faktu, iż liturgia jest środowiskiem, w którym pogłębia się rozumienie słowa Bożego. Ono się aktualizuje i staje się ciałem ${ }^{28}$.

Odniesienie do ścisłego związku między słowem Bożym i liturgią znajdujemy w konstytucji o liturgii świętej Sacrosanctum Concilium, do której nawiązuje Benedykt XVI. Czytamy w niej, że „Pismo Święte ma doniosłe znaczenie $\mathrm{w}$ sprawowaniu liturgii. $\mathrm{Z}$ niego bowiem pochodzą czytania, które wyjaśnia się w homilii, oraz psalmy przeznaczone do śpiewu. Z niego czerpią natchnienie i ducha prośby, modlitwy i pieśni liturgiczne. W nim też trzeba szukać sensu czynności i znaków"29.

Nauczanie soborowe kieruje uwagę na liturgię słowa, w której rola Słowa Bożego jest w sposób szczególny uwidoczniona. W tej części każdej celebracji liturgicznej w centrum jest zawsze osoba Jezusa Chrystusa Boga przemawiającego do swego ludu, a tym samym aktualizującego tajemnice odkupienia i zbawienia oraz wzywającego do szukania i wypełniania woli Ojca. Podczas celebracji liturgii Kościołowi towarzyszy wiara, że mówi do niego sam Chrystus. Dzieje się tak, ponieważ „jest obecny w swoim słowie, bo gdy w Kościele czyta się Pismo Święte, On sam przemawia" ${ }^{30}$. W liturgii tekst pisany staje się ponownie Słowem żywym i działającym. Tym przywilejem obecności Syna Bożego w pro-

\footnotetext{
26 Por. M. Pyc, dz. cyt., s. 18; por. VD 51.

27 Por. VD 52.

28 Por. B. Nadolski, Leksykon liturgii, Poznań 2006, s. 1464.

29 KL 24; por. VD 52.

$30 \mathrm{KL} 7$.
} 
klamowanym Słowie Bożym cieszy się zarówno lektura Starego i Nowego Testamentu, jak również homilia, która jest eksplikacją tego słowa ${ }^{31}$.

Czytania biblijne wymagają wyjaśnienia bądź też swego rodzaju komentarza. Benedykt XVI wskazuje na niezwykle ważną rolę, jaką odgrywa homilia, która stanowi część czynności liturgicznej. To właśnie ona aktualizuje przesłanie Pisma Świętego. Dzieje się tak, aby wierni w swojej codzienności mieli możliwość odkrycia obecności i skuteczności Słowa Bożego. Homilia jest bowiem podjęciem dialogu Pana ze swoim ludem. Stanowi jego najwyższy moment. Jej zadaniem jest również ułatwienie zrozumienia sprawowanej tajemnicy, a także przygotowanie zgromadzonych wiernych do wyznania wiary, modlitwy powszechnej i w końcu liturgii eucharystycznej. Niezbędne jest więc solidne i sumienne przygotowanie osób odpowiedzialnych za głoszenie Słowa. Potrzeba, by często pochylali się nad Pismem Świętym, pozostając z nim w głębokiej zażyłości ${ }^{32}$.

Rozumienie liturgii słowa jako przestrzeni odczytywania i wyjaśniania Słowa Bożego prowadzi do stwierdzenia, że jest ona posiłkiem. Ojcowie Kościoła porównywali Słowo Boże do pokarmu. Według nich słuchanie słowa Bożego jest równoznaczne z karmieniem się Chrystusem. Konstytucja Sacrosanctum Concilium podkreśla, że wierni, będąc kształtowanymi przez słowo Boże, posilają się przy stole Ciała Pańskiego. Skuteczność zaś Słowa Bożego podyktowana jest działaniem Ducha Świętego ${ }^{33}$.

W kontekście obecności Słowa Bożego w liturgii Benedykt XVI bardzo mocno akcentuje działanie Ducha Świętego. Stwierdza, że to dzięki Jego mocy Słowo Boże głoszone w liturgii jest ciągle żywe i skuteczne. To Duch Święty sprawia, iż Słowo Boże oddziałuje na serca ludzi wierzących, jednocześnie przemieniając je i pobudzając do złożenia ofiary duchowej ${ }^{34}$. Jego działanie „zaszczepia w serce każdego z uczestników to, co podczas proklamacji słowa Bożego jest głoszone całemu zgromadzeniu wiernych,

${ }^{31}$ Por. Papieska Komisja Biblijna, Interpretacja Biblii w Kościele, s. 93; por. B. Nadolski, Liturgika. Eucharystia, t. IV, Poznań 1992, s. 161-162.

32 Por. VD 59; por. Franciszek, Adhortacja apostolska Evangelii gaudium, Kraków 2013, 137; por. OWMR 29; por. KO 25.

${ }^{33}$ Por. KL 48; por. B. Nadolski, Liturgika. Eucharystia, t. IV, s. 162; por. B. Nadolski, Leksykon liturgii, s. 1465.

34 Por. VD 52; por. M. Pyc, dz. cyt., s. 18. 
umacnia jedność wszystkich, podtrzymuje różnorakie dary łaski i dodaje siły do wypełnienia wielorakich zadań" ${ }^{35}$.

Działaniu Ducha Świętego Słowo Boże zawdzięcza swój dynamizm, przez który chce obudzić wiarę i ją zaktywizować. Pragnie uczyć czci wobec jej wielkiej tajemnicy. Tu w sposób szczególny ujawnia się dialogiczny charakter Słowa Bożego. Ono ze swej natury wzywa człowieka do dialogu. Dlatego też uczestnictwo w liturgii słowa niejako warunkuje owocność udziału w liturgii eucharystycznej ${ }^{36}$.

Benedykt XVI zaznacza, że szczególnym miejscem obecności i głoszenia Słowa Bożego są Eucharystia i Liturgia Godzin. To właśnie w tych celebracjach jest obecne urzeczywistniające się sakramentalnie Misterium Paschalne. W taki sposób Kościół, obchodząc tajemnice odkupienia, otwiera skarbiec zbawczych czynów Chrystusa, które uobecniając się w każdym czasie, dają wiernym możliwość zetknięcia się z nimi, a tym samym dostąpienia łaski zbawienia ${ }^{37}$.

Papież Benedykt XVI w swojej adhortacji o Słowie Bożym bardzo mocno podkreśla związek zachodzący między Pismem Świętym a działaniem sakramentalnym. Można stwierdzić, że słowo i sakrament są sobie ściśle przyporządkowane, wzajemnie się konstytuują, a co za tym idzie tworzą całość liturgii. Między tymi rzeczywistościami istnieje pewien rodzaj przenikania się i to sprawia, że tworzą one jeden akt kultu: „Dwie części, z których niejako składa się Msza Święta, mianowicie liturgia słowa i liturgia eucharystyczna, tak ściśle łączą się ze sobą, że stanowią jeden akt kultu"38.

Ojciec Święty Benedykt XVI w Verbum Domini jasno wyraża swoją myśl w tej kwestii:

Słowo i Eucharystia tak ściśle przynależą do siebie, że nie można zrozumieć pierwszego bez drugiej: Słowo Boże staje się sakramentalnym ciałem w wydarzeniu eucharystycznym. Eucharystia otwiera nas na zrozumienie Pisma Świętego, tak jak Pismo Święte oświeca i wyjaśnia tajemnicę

$35 \mathrm{VD} 52$.

36 Por. M. Rusecki, Traktat o Objawieniu, Kraków 2007, s. 514; por. B. Nadolski, Leksykon liturgii, s. 1464.

37 Por. VD 52.

38 KL 56. 
eucharystyczną. Faktycznie, jeśli nie uzna się, że Pan jest realnie obecny w Eucharystii, rozumienie Pisma pozostaje niepełne ${ }^{39}$.

Myśl ta pokazuje, że obie rzeczywistości liturgiczne, czyli słowo Boże i Eucharystia przynależą do siebie i wewnętrznie się ze sobą łączą w sposób tak ścisły, iż nie można ich rozpatrywać bez wzajemnego odniesienia. Od początku swojego istnienia Kościół gromadził wiernych, aby głosić słowo Boże oraz uobecniać dzieło zbawienia przez celebrację liturgii eucharystycznej.

Odkrycie i pogłębienie związku słowa i sakramentu oraz poznanie sprawczego charakteru słowa Bożego w działaniu sakramentalnym pozwala papieżowi mówić o sakramentalności Słowa. Pierwszym źródłem sakramentalności Słowa Bożego według Benedykta XVI jest tajemnica wcielenia: „Słowo stało się Ciałem” (J 1,14). To w tym momencie Słowo Boże weszło w historię i w czas, objawiając tym samym Ojca i pełnię Bożego Objawienia ${ }^{40}$. We Wcieleniu rzeczywistość objawionej tajemnicy staje się dostępna w ciele Jezusa Chrystusa. Dzięki temu Słowo Boże jest postrzegane przez wiarę za pośrednictwem znaku, którym są słowa i ludzkie gesty. Potrzebna jest tutaj wiara, gdyż ona rozpoznaje Słowo Boże, poprzez przyjęcie gestów i słów, w których Chrystus się objawia światu. Papież pisze: „Sakramentalny horyzont Objawienia wskazuje zatem na okoliczności historyczno-zbawcze, w których Słowo Boże wkracza w czas i przestrzeń, stając się interlokutorem człowieka wezwanego do przyjęcia w wierze Jego daru"41.

Sakramentalność Słowa Bożego staje się zrozumiała przez analogię do rzeczywistej obecności Chrystusa pod postaciami chleba i wina w Eucharystii. Kościół zawsze wierzył, że w „Najświętszym sakramencie Eucharystii są zawarte prawdziwie, rzeczywiście i substancjalnie Ciało i Krew wraz z duszą i Bóstwem Pana naszego Jezusa Chrystusa, a więc cały Chrystus" ${ }^{\prime 2}$. W Komunii Świętej wierzący rzeczywiście przyjmują prawdziwe Ciało i Krew Chrystusa. Wyznanie wiary w obecność Chry-

\footnotetext{
39 VD 55.

${ }^{40}$ Por. VD 56; por. tamże, 73.

${ }^{41}$ VD 56.

${ }^{42}$ KKK 1374; por. Sobór Trydencki, Dekret o sakramencie Eucharystii, BF, 406,
} s. 204; por. A. Szafrański, Teologia liturgii eucharystycznej, Lublin 1981, s. 130-142. 
stusa pod postaciami eucharystycznymi pociąga za sobą również wiarę w to, że jest On obecny i mówi do zgromadzonych także poprzez Słowo Boże proklamowane podczas Eucharystii ${ }^{43}$.

\section{GŁOSZENIE SŁOWA BOŻEGO POSŁANNICTWEM KOŚCIOŁA}

Głoszenie słowa Bożego nie może odbywać się tylko w ściśle określonych grupach. Papież Benedykt XVI naucza w Verbum Domini, że Kościół musi być otwarty na Ducha Świętego, który posyła głosicieli Słowa Bożego na krańce świata. Papież Benedykt XVI naucza, że „Kościół w swej istocie jest misyjny. Nie możemy zatrzymywać dla siebie słów życia wiecznego, które daje nam Jezus Chrystus, gdy Go spotykamy: one są dla wszystkich, dla każdego człowieka"44. Skoro każdy wierny usłyszał kiedyś Słowo Boże, to jego zadaniem staje się dawanie świadectwa o zmartwychwstałym Chrystusie na całym świecie. Apostoł Paweł bardzo mocno powiedział: „Biada mi, gdybym nie głosił Ewangelii” (1Kor 9,16). Natomiast Dyrektorium duszpasterstwa służby liturgicznej stwierdza, że „Każdy z pełniących w liturgii świętą czynność powinien być w codziennym życiu wspólnoty świadkiem Chrystusa i gorliwie wypełniać powierzone mu zadania wobec braci" ${ }^{45}$.

Misyjna działalność Kościoła rozpoczęła się już w Wieczerniku, kiedy Jezus ukazał się uczniom i wypowiedział do nich następujące słowa: „Idźcie więc i nauczajcie wszystkie narody, udzielając im chrztu w imię Ojca i Syna, i Ducha Świętego” (Mt 28,19). Papież również odnosi się do tego wydarzenia i podaje, że „Duch Zmartwychwstałego uzdalnia nasze życie do skutecznego głoszenia Słowa na całym świecie. Jest to doświadczenie pierwszej wspólnoty chrześcijańskiej, która szerzyła Słowo przez przepowiadanie i świadectwo"46. Przy tym uświadamia cały Kościół, że na wszystkich jego członkach spoczywa obowiązek głoszenia Słowa Bożego, które wcześniej otrzymał ${ }^{47}$.

\footnotetext{
${ }^{43}$ Por. KL 7; por. A. Szafrański, dz. cyt., s. 147-160.

${ }^{44}$ DV 91.

${ }^{45}$ Dyrektorium duszpasterstwa stużby liturgicznej, Kraków 2009, n. 34.

46 VD 91.

47 Por. tamże.
} 
Przepowiadając Słowo na innych kontynentach, Kościół dociera do wielu kultur, ale przede wszystkim do ludzi, którzy może jeszcze nie słyszeli o Bogu. W encyklice Deus Caritas est papież zwraca uwage na to, że miłość do Boga i miłość do bliźniego muszą iść w parze. Jednocześnie stwierdza, że zamykanie oczu na bliźniego jest zamykaniem oczu na Boga ${ }^{48}$.

Skoro cały Kościół ma być misyjny, to również jego dzieci muszą posiadać ten charyzmat i poczucie odpowiedzialności za tych, którzy jeszcze o Bogu nie słyszeli. Dyrektorium o posłudze i życiu kapłanów wspomina o tym obowiązku i jednocześnie podaje, że „To wymaganie życia Kościoła w świecie współczesnym powinno być odczuwane i przeżywane przede wszystkim w sposób istotny przez każdego kapłana jako dar, który należy przeżywać w ramach jego ustanowienia"49. Dyrektorium zwraca również uwagę na to, że jest to obowiązek wynikający z przynależności do Kościoła, który chce gromadzić wszystkich w Jezusie Chrystusie ${ }^{50}$.

Papież Benedykt zwraca uwagę, że „Tym, co Kościół głosi światu, jest bowiem Logos nadziei" ${ }^{1}$. Tym Logosem jest Jezus Chrystus, o którym pisze Ewangelista Jan (J 1,1-14). Ojciec Święty tym określeniem Jezusa rozpoczyna swoją adhortację ${ }^{52}$. Logos - Słowo Boże - Jezus Chrystus są określeniami Syna Bożego. Spotkanie z Chrystusem, który jest obecny w Słowie, niesie ze sobą bardzo konkretne doświadczenie wiary i miłości. Doświadczenie mocy Słowa Bożego staje się jednocześnie doświadczeniem miłości tegoż Słowa. Benedykt XVI w encyklice Deus Caritas Est naucza: „Spotkanie z widzialnymi przejawami miłości Boga może wzbudzić w nas uczucie radości, jakie rodzi doznania, że jest się kochanym" ${ }^{53}$.

W dalszej części adhortacji Dei Verbum Ojciec Święty przypomina, że głoszenie Słowa Bożego jest czymś naturalnym, czymś powszechnym i w końcu czymś, co wynika $\mathrm{z}$ „samej natury wiary” ${ }^{4}$. To szczególne

${ }^{48}$ Zob. Benedykt XVI, Encyklika Deus Caritas est, Poznań 2006, n. 16.

49 Kongregacja ds. Duchowieństwa, Dyrektorium o posłudze i życiu kapłanów, Poznań 1998, n. 15.

50 Por. tamże.

51 VD 91.

52 Tamże 1.

${ }^{53}$ Benedykt XVI, Encyklika Deus Caritas est, n. 17.

${ }^{54} \mathrm{VD} 92$. 
zadanie stojące przed całym Kościołem pochodzi od samego Boga. Nie jest ono wymysłem ludzkim, by zaspokajać własne ambicje, ale jest nakazem Chrystusa. Dekret o misyjnej działalności Kościoła przypomina, że „Chrystus posłał od Ojca Ducha Świętego, aby dokonywał wewnętrznie swojego zbawczego dzieła i nakłania Kościół do rozszerzania się" ${ }^{55}$.

Działalność misyjna niesie ze sobą konkretny cel. Benedykt XVI tak się o nim wyraża: „trzeba więc coraz bardziej odkrywać konieczność i piękno głoszenia Słowa, aby mogło zapanować królestwo Boże, o którym nauczał sam Chrystus" ${ }^{56}$. Można w tym miejscu zapytać: do kogo należy zadanie głoszenia Dobrej Nowiny? Czy tylko do kapłanów i osób konsekrowanych? Papież bardzo jasno i konkretnie odpowiada na to pytanie:

Nikt $\mathrm{z}$ wierzących $\mathrm{w}$ Chrystusa nie jest zwolniony $\mathrm{z}$ tej odpowiedzialności, która wynika z sakramentalnej przynależności do Ciała Chrystusa. Świadomość ta powinna być rozbudzana w każdej rodzinie, parafii, wspólnocie, stowarzyszeniu i ruchu kościelnym. Cały Kościół jako tajemnica komunii jest zatem misyjny i każdy, zgodnie ze swoim stanem życia, jest powołany do tego, by wnieść znaczący wkład w głoszenie chrześcijańskiego orędzia ${ }^{57}$.

Mimo że cały Kościół jest misyjny, to jednak od pewnych grup wymaga się większego zaangażowania w głoszenie Słowa Bożego. Są to przede wszystkim biskupi i prezbiterzy, którzy są jako pierwsi są wezwani głoszenia Słowa. Papież wspomina również o osobach życia konsekrowanego, a także o diakonach, którym została powierzona odpowiedzialność za głoszenie Dobrej Nowiny ${ }^{58}$. Również soborowy Dekret o misyjnej działalności Kościoła zwraca na to uwagę i podaje najważniejsze wytyczne, którymi powinni kierować się moderatorzy w formowaniu alumnów. Zwraca uwagę na to, że

za najważniejsze należy uznać to, co jest powiedziane o potrzebie ścisłego łączenia przygotowania duchowego z doktrynalnym i duszpasterskim, o prowadzeniu życia zgodnego z Ewangelią, bez oglądania się na korzyść własną albo rodziny, i o podkreślaniu głębokiego znaczenia misterium

\footnotetext{
${ }^{55} \mathrm{DM} 4$.

${ }^{56}$ VD 94

57 Tamże, 94.

58 Tamże.
} 
Kościoła. [...] Aby osiągnąć ten zasadniczy cel, cała formacja alumnów winna być ujmowana $\mathrm{w}$ świetle misterium zbawienia, jak to jest przedstawione w Piśmie Świętym ${ }^{59}$.

Kolejną grupą odpowiedzialną za głoszenie Słowa Bożego są wszyscy ochrzczeni. Przez przyjęty sakrament chrztu i życie we wspólnocie Kościoła mają oni dzielić się tym, czego sami doświadczają. Ich świadectwo i głoszenie Słowa Bożego będzie miało z pewnością inny wymiar, ale również bardzo ważny. Papież zaznacza, że „Świeccy są powołani do tego, by wykonywali swoje prorockie zadanie, wynikające bezpośrednio z chrztu, i świadczyli o Ewangelii w życiu codziennym, wszędzie, gdzie są"60. Natomiast w dekrecie o apostolstwie świeckich czytamy: „Obowiązek i prawo świeckich do apostolstwa wypływa z ich zjednoczenia z Chrystusem Głową. Przez chrzest bowiem wszczepieni w Ciało Mistyczne Chrystusa, przez bierzmowanie umocnieni mocą Ducha Świętego, przez samego Pana przeznaczeni są do apostolstwa”61. I dalej dodaje: „Wszystkim zatem wiernym zlecony jest wspaniały obowiązek współdziałania, by Boska Nowina o zbawieniu została poznana i przyjęta przez wszystkich ludzi na całym świecie" ${ }^{62}$. Konstytucja dogmatyczna o Kościele Lumen gentium naucza: „Boskie posłannictwo, powierzone przez Chrystusa Apostołom, trwać będzie do końca wieków. Ponieważ Ewangelia, którą mają przekazywać, jest dla Kościoła po wszystkie czasy źródłem całego jego życia”" ${ }^{3}$.

Papież Benedykt podkreśla, że misji Kościoła polegającej na głoszeniu Słowa Bożego nie można traktować jako nieobowiązkowej lub dodatkowej części życia kościelnego. Jest to misja podstawowa i fundamentalna. Oznacza to, że każdy, kto jest włączony przez chrzest w życie Kościoła, w odpowiedni dla danej osoby sposób ma uczestniczyć w tej wyjątkowej misji Kościoła. Choć nie wszyscy mogą wyjechać na misje, aby innym narodom głosić orędzie dobrej nowiny, to jednak papież bardzo mocno zachęca do missio ad gentes i naucza: „W żadnym wypadku Kościół nie może się ograniczyć do duszpasterstwa zachowawczego, przeznaczonego
59 DM 16.
60 VD 94.
61 DA 3.
62 Tamże.
63 KK 20. 
dla tych, którzy już znają Ewangelię Chrystusa. Misyjny zapał jest wyraźną oznaką dojrzałości wspólnoty kościelnej” ${ }^{64}$.

Papież Franciszek w adhortacji Evangelii Gaudium wyjaśnia, że „bycie Kościołem oznacza bycie Ludem Bożym, zgodnie z wielkim planem miłości Ojca. Pociąga to za sobą bycie zaczynem Bożym pośród ludzkości. Oznacza to głoszenie i niesienie Bożego zbawienia w ten nasz świat" ${ }^{65}$. Oznacza to, że bycie zaangażowanym w życie Kościoła wiąże się jednocześnie z otwartością na misje.

Chrześcijanin nie musi się lękać głoszenia Słowa Bożego. Papież Franciszek zachęca i podnosi na duchu:

Ci, którzy głoszą Ewangelię, powinni bez lęków otworzyć się na działanie Ducha Świętego. W dniu Pięćdziesiątnicy Duch sprawił, że Apostołowie wyszli ze swych ograniczeń i zostali przemienieni w głosicieli wielkich dzieł Bożych, których każdy zaczyna rozumieć w swoim własnym języku. Ponadto Duch Święty obdarza siłą do głoszenia nowości Ewangelii śmiało, głośno, w każdym czasie i miejscu, także pod prąd ${ }^{66}$.

Współczesny apostoł nie może się martwić tym, jak będzie wyglądało jego ewangelizowanie. To Duch Święty, który zstąpił na Apostołów, również i jego uzdolni do głoszenia Słowa Bożego. Głosiciele Słowa Bożego jako ludzie ochrzczeni muszą otworzyć się na Jego działanie. Trzeba otworzyć się na Kościół, z którego wychodzi Duch. Obowiązek przepowiadania w Kościele bierze się z samego serca Kościoła i należy do jego najważniejszych zadań.

\section{ZAKOŃCZENIE}

Słowo Boże znajduje się w centrum życia Kościoła. Ono stanowi jeden z jego najważniejszych fundamentów. Podobnie jak sakramenty, tak również Słowo Boże buduje, ożywia i umacnia Kościół. Szczególne miejsce Słowo Boże zajmuje w liturgii Kościoła, która jest źródłem i szczytem jego życia i działania. W liturgii głoszone Słowo Boże uobecnia się i aktualizu-

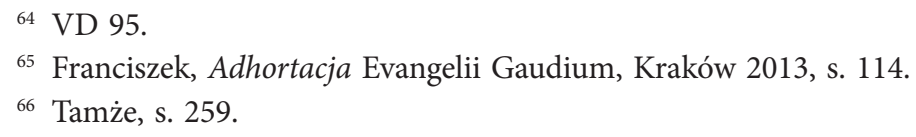


je. Papież mówi wprost o sakramentalności Słowa Bożego. To stwierdzenie jest czymś nowym w nauczaniu Kościoła w odniesieniu do Słowa Bożego głoszonego w liturgii Kościoła. Daje także przyzwolenie, aby w pisowni używać wielkich liter. Znaczenie i walor Słowa Bożego sprawia, że jego głoszenie stanowi podstawowe i najważniejsze posłannictwo Kościoła.

Z nauczania Benedykta XVI jasno wynika, że bez Słowa Bożego nie byłoby Kościoła, bo to właśnie Logos - Słowo Boże - Syn Boży jest jego założycielem i fundamentem.

Z powyższych treści rodzą się wnioski pastoralne, aby jeszcze bardziej dowartościować Słowo Boże w życiu Kościoła. W związku z tym należy z ogromną odpowiedzialnością podejść do kwestii formacji głosicieli Słowa Bożego, zarówno duchownych, jak i świeckich. Potrzeba tu przygotowania teologicznego oraz duchowego. Głoszenie Słowa Bożego winno stać się owocem wiary, która rodzi się z usłyszenia i przyjęcia dobrej nowiny. Owocem żywej wiary będzie świadectwo życia i moc w głoszeniu Słowa Bożego. Doświadczenie mocy Słowa Bożego ma mieć przełożenie na jakość homilii i katechezy.

Streszczenie. Artykuł ukazuje eklezjalny wymiar głoszenia Słowa Bożego w Kościele i w świecie na podstawie adhortacji apostolskiej papieża Benedykta XVI. W papieskim nauczaniu Kościół jest najpierw właściwym i jedynym miejscem poprawnej teologicznie hermeneutyki Słowa Bożego. Ojciec Święty bardzo mocno akcentuje nieustanną obecność Słowa Bożego w Kościele. Nazywa Kościół Domem Słowa Bożego, a uprzywilejowaną przestrzenią jego głoszenia jest liturgia. W liturgii Kościoła głoszone Słowo Boże uobecnia się i aktualizuje. Papież mówi wprost o sakramentalności Słowa Bożego. To stwierdzenie jest czymś nowym w nauczaniu Kościoła w odniesieniu do Słowa Bożego głoszonego w liturgii Kościoła. Daje także przyzwolenie, aby w pisowni używać wielkich liter. Znaczenie i walor Słowa Bożego sprawia, że jego głoszenie stanowi podstawowe i najważniejsze posłannictwo Kościoła. Z nauczania papieża jasno wynika, że Słowo Boże buduje i umacnia Kościół. Ono jest jednym z jego silnych fundamentów. Bez Słowa Bożego nie byłoby Kościoła, bo to właśnie Logos - Słowo Boże - Syn Boży jest jego założycielem i fundamentem. Można stwierdzić, że adhortacja apostolska Verbum Domini wnosi ogromny wkład do tej części teologii, która nazywa się eklezjologią. Eklezjologia jako punkt wyjścia i dojścia musi zawsze brać Słowo Boże. Nie ma eklezjologii bez Słowa Bożego.

Słowa kluczowe: Słowo Boże; Kościół; eklezjologia; głoszenie; hermeneutyka; sakramentalność; obecność. 
Abstract. The Ecclesial Dimension of the Proclamation of the Word of God in the Light of Benedict XVI's Apostolic Exhortation "Verbum Domini". The article discusses the ecclesial dimension of the proclamation of the word of God in the Church and in the world on the basis of Benedict XVI's Apostolic Exhortation "Verbum Domini". The Papal teaching first presents the Church as the actual and only place for proper theological hermeneutics of the word of God. The Holy Father emphasizes very strongly the constant presence of the word of God in the Church. He calls the Church the "home of the word", whereas a privileged space for the proclamation of the word of God is the liturgy. In the liturgy of the Church the proclaimed word of God is made present and achieves the purpose for which it is proclaimed. The Pope speaks directly about the sacramentality of the word of God. This is a new expression in the teaching of the Church in so far as the word of God is concerned, as it is proclaimed in the Church's liturgy. It allows for the use of capital letters when referring to God's word. The meaning and value of the word of God make it possible for its proclamation to become the most fundamental and most important mission of the Church. The Pope's teaching also leads to the conclusion that the word of God builds up the Church and strengthens it. The word of God is the Church's strongest foundation. Without the word of God the Church would not exist, because the Logos as the Word is the Son of God who founded the Church and remains its foundation. One can say that the Apostolic Exhortation "Verbum Domini" contributes immensely to the theological field of ecclesiology. Ecclesiology as a point of departure and an end must always draw its vitality from the word of God. There is no ecclesiology without the word of God.

Key words: Word of God; Church; ecclesiology; proclamation; hermeneutics; sacramentality; presence. 